\title{
Brain serotonin depletion enhances the sodium appetite induced by sodium depletion or beta-adrenergic stimulation
}

\author{
HAWLINSTON R. C. LIMA, HAERISHTON R. CAVALCANTE-LIMA, PEDRO L. CEDRAZ-MERCEZ, \\ RICARDO H. COSTA-E-SOUSA, EMERSON L. OLIVARES, DANIEL BADAUÊ-PASSOS-Jr, \\ MAGDA A. MEDEIROS, WELLINGTON S. CÔRTES and LUÍS C. REIS \\ Department of Physiological Sciences, Institute of Biology, UFRRJ, 23890-000 Seropédica, RJ, Brasil
}

Manuscript received on July 14, 2003; accepted for publication on October 1, 2003;

presented by GERHARD MALNIC

\begin{abstract}
We investigate the influence of brain serotonin depletion on the sodium appetite. Rats depleted of serotonin through the systemic administration of p-chlorophenylalanine $(300 \mathrm{mg} / \mathrm{kg}$, ip, for 2 days) showed an intense natriorexigenic response induced by sodium depletion (furosemide, $20 \mathrm{mg} / \mathrm{kg}, s c, 24 \mathrm{~h}$ before water and $1.8 \% \mathrm{NaCl}$ presentation). Intake of $1.8 \% \mathrm{NaCl}$ was always higher than that observed for the control group $(12.9 \pm 1.4$ and $21.4 \pm 3.0 \mathrm{~mL}$ vs $5.7 \pm 1.2$ and $12.7 \pm 1.6 \mathrm{~mL}, 30$ and $300 \mathrm{~min}$ after water and saline presentation). After $24 \mathrm{~h}$, the natriorexigenic response continued to be significantly higher compared to control (33.6 \pm 5.1 vs $21.9 \pm 3.6 \mathrm{~mL}, P<0.05)$. Fourteen days after p-chlorophenylalanine administration, $1.8 \% \mathrm{NaCl}$ intake did not differ from controls. Serotonin-depleted rats expressed an early natriorexigenic response after isoproterenol administration on the third day after the first injection of p-chlorophenylalanine. An increase in $1.8 \% \mathrm{NaCl}$ intake was first observed at $120 \mathrm{~min}(1.9 \pm 0.2$ vs $0.45 \pm 0.3 \mathrm{~mL}, P<0.05)$ and remained high up to the end of the 24-h observation period (17.3 \pm 3.2 vs $1.1 \pm 0.5 \mathrm{~mL}, P<0.05)$. After 7 and 14 days, the natriorexigenic response became comparable to that of control animals. Present results show that brain serotonin depletion exaggerates the sodium appetite induced by the paradigm of sodium depletion or after beta-adrenergic stimulation.
\end{abstract}

Key words: sodium appetite, brain serotonin depletion, sodium and water depletion, isoproterenol, serotonergic system.

\section{INTRODUCTION}

Serotonergic circuits originating from the mesencephalic raphe have been implicated in waterelectrolyte homeostasis (Reis et al. 1994, Franchini et al. 2002, McCann et al. 2003). Electrolytic lesions in the dorsal raphe nucleus (DRN) induce a drastic decrease in the release of atrial natriuretic peptide under basal conditions or after blood volume expansion (Reis et al. 1994). Rats with electrolytic

Correspondence to: Luís Carlos Reis

E-mail: 1creis@ufrrj.br
DRN lesions offered water through an orogastric tube develop antinatriuresis, a condition correlated with the previous observations. Sodium depletion induced by peritoneal dialysis evokes an increase in the expression of c-Fos immunoreactivity in the nucleus tractus solitarius, in the DRN and in prosencephalic structures implicated in water-electrolyte regulation, such as the lamina terminalis (Franchini et al. 2002). These observations, in turn, are in agreement with the demonstration of an increase in renal sodium excretion after intracerebroventricular 
administration of 5-HT2 serotonergic agonists (Reis et al. 1991). Recently, our laboratory obtained new evidence for a role of the DRN in this context. Electrolytic or excitotoxic lesions produced with the excitatory amino acid, ibotenic acid, induced an increase in spontaneous sodium appetite after volume depletion or after stimulation with elicitors of systemic angiotensin II (ANG II) production (submitted for publication).

Brain serotonergic hypofunction has been implicated in the genesis of affective disorders such as anxiety and depression (Meltzer and Lowy 1987, Curzon 1988, Charney et al. 1990). Within this context, humans showing signs of anxiety and depression have an increased risk of developing hypertension (Jonas and Lando 2002, Zamorski and Ward 2000, Ostroumova et al. 2002, Rutledge and Hogan 2002). Sodium appetite represents a homeostatic behavior which is suggested to play a role in the regulation of extracellular fluid volume; thus, increased ingestion of sodium chloride may contribute to the induction of water-electrolyte and cardiovascular alterations, followed by hypertension (Denton et al. 1984, 1995, Fitzsimons 1998).

The objective of the present study was to determine the influence of brain serotonin depletion on sodium appetite induced by volume depletion or after systemic $\beta$-adrenergic stimulation. Brain serotonin depletion is a classical experimental paradigm used in neurobiological studies and is induced by the administration of $\mathrm{p}$-chlorophenylalanine, a competitor of tryptophan and an irreversible inhibitor of tryptophan hydroxylase (TPO) (Koe and Weissman 1966, Cooper et al. 1996).

\section{MATERIALS AND METHODS}

Male Wistar rats weighing 300 to $350 \mathrm{~g}$ housed in a room under a controlled light-dark cycle $(12 \mathrm{~h}$ light/12 h dark) and at a controlled temperature of $25^{\circ} \mathrm{C}$ were used. All experiments were performed according to current Brazilian legislation on animal experimentation. The animals selected for the experiments were first accommodated to metabolic cages equipped with a food container and two volumetric drinking bottles, with rat chow, water and $1.8 \% \mathrm{NaCl}$ being available ad libitum. $\mathrm{NaCl}$ at a concentration of $1.8 \%$ is aversive to the taste but is consumed under experimental conditions of body sodium and water depletion, with a subsequent attenuation of aversion and increase in sodium intake (natriorexigenic response) (Menani et al. 1996, Fitzsimons 1998, Badauê-Passos et al. 2003). Brain serotonin depletion was induced by treatment with p-chlorophenylalanine methylester hydrochloride (PCPA; Sigma, St. Louis, MO, USA) at the dose of $300 \mathrm{mg} / \mathrm{kg}$, ip , for 2 days. PCPA is a modified amino acid that competes with tryptophan for the same transporter on serotonergic neurons. In addition, after neuronal uptake PCPA irreversibly inhibits TPO. This experimental maneuver induces a drastic decrease in serotonin content, possibly reproducing clinical conditions in which this brain indolamine becomes deficient and which have been implicated in the genesis of affective disorders (Cooper et al. 1996).

The animals were divided into the following groups:

I) Rats treated with isotonic saline $(1 \mathrm{~mL} / \mathrm{kg}, s c$, $\mathrm{N}=9)$ or PCPA $(n=11)$ were injected with furosemide (Lasix, Aventis, Suzano, SP, Brazil) $(20 \mathrm{mg} / \mathrm{kg}, s c)$ on the second, sixth and thirteenth day after the first injection of PCPA. For the following $24 \mathrm{~h}$, the animals only received a low-sodium diet (maize flour cooked with little distilled water and without salt). On the next day, water and $1.8 \% \mathrm{NaCl}$ were reintroduced in the drinking bottles for the assessment of water intake and sodium appetite at 60-min intervals for $300 \mathrm{~min}$ and after $24 \mathrm{~h}$ as described elsewhere (Menani et al. 1996, de Luca et al. 2002) (see protocol in the Fig. 1A).

II) Rats received isotonic saline ( $1 \mathrm{~mL} / \mathrm{kg}, s c, n=$ $12)$ or ( \pm )-isoproterenol hydrochloride (ISO; Sigma) (300 $\mu \mathrm{g} / \mathrm{kg}, s c, n=12)$ on the third, seventh and fourteenth day after the first injection of PCPA (see protocol in the Fig. 1B). 
This $\beta$-adrenergic agonist is a potent dipsogenic agent whose action is dependent on the systemic release of renin and on the afferent activation of baroreceptors after a fall in arterial pressure (Houpt and Epstein 1971, Reis et al. 1992, Fitzsimons 1998). Immediately after isoproterenol injection, the animals were returned to the metabolic cages and submitted to the same procedures for the assessment of water and $1.8 \% \mathrm{NaCl}$ intake as described above.

The results are reported as means $\pm \mathrm{SE}$. The paired or unpaired Student $t$-test was used when appropriate. Comparisons between groups were made by two-tailed ANOVA and differences between means were considered to be significant when $P \leq$ 0.05 .

\section{RESULTS}

Rats treated with PCPA and depleted of sodium and water by previous administration of furosemide developed an intense sodium appetite 3 days after administration of the TPO inhibitor. Intake of $1.8 \%$ $\mathrm{NaCl}$ reached mean values always higher than those observed for the control group (12.9 \pm 1.4 and 21.4 \pm $3.0 \mathrm{~mL}$ vs $5.7 \pm 1.2$ and $12.7 \pm 1.6 \mathrm{~mL}, 30$ and 300 min after fluid presentation, $P<0.05)$. At the end of the 24-h observation period, the natriorexigenic response continued to be significantly higher compared to control $(33.6 \pm 5.1$ vs $21.9 \pm 3.6 \mathrm{~mL}, P<$ 0.05) (Fig. 2). The dipsogenic response showed a similar ingestion pattern (Fig. 3). Seven days after the administration of PCPA, $1.8 \% \mathrm{NaCl}$ and water intake did not differ from the values obtained for the control group (Figs. 2 and 3). Interestingly, 7 days after treatment wit PCPA, the natriorexigenic response elicited by furosemide was found to be below control levels $(5.9 \pm 0.9$ vs $12.7 \pm 1.6 \mathrm{~mL}$, at 300 min, $P<0.05)$, while after 14 days the difference was no longer significant $(9.1 \pm 1.8$ vs $12.7 \pm 1.6$ $\mathrm{mL}$, at $300 \mathrm{~min}, P>0.05$ ) (Fig. 2).

Serotonin-depleted rats showed an early natriorexigenic response after the administration of isoproterenol on the third day after the first injection of
PCPA (Fig. 4). The increase in $1.8 \% \mathrm{NaCl}$ intake was first observed at $120 \mathrm{~min}$ after fluid presentation $(1.9 \pm 0.3$ vs $0.45 \pm 0.3 \mathrm{~mL}, P<0.05)$ and continued to be elevated up to the end of the 24-h observation period $(17.3 \pm 3.2$ vs $1.1 \pm 0.5 \mathrm{~mL}$, $P<0.05)$. After 7 and 14 days, the natriorexigenic response became comparable to that observed for the control group (Fig. 4).

Similarly, the dipsogenic response and the resulting water intake after isoproterenol administration were more intense than those observed in control animals under the same conditions (Fig. 5). Again, after 7 and 14 days the dipsogenic response induced by $\beta$-adrenergic stimulation did not differ from controls (Fig. 5b).

\section{DISCUSSION}

Sodium appetite represents one component of the homeostatic behavior implicated in the regulation of extracellular fluid volume (Fitzsimons 1998). Data from our laboratory have shown that serotonergic neurons of the mesencephalic raphe, also involved in the regulation of affective behavior, influence sodium appetite (submitted for publication). In this context, brain serotonin depletion induced by the administration of PCPA represents a classical model of serotonergic hypofunction (Koe and Weissman 1966, Cooper et al. 1996). Electrolytic or ibotenic lesion of the DRN, a mesencephalic nucleus that contains an important contingent of rostrally projecting serotonergic neurons, induces an increase in basal $1.8 \% \mathrm{NaCl}$ intake and exacerbates the natriorexigenic response elicited by various paradigms. The results obtained in the present study confirm this assumption. In the model of sodium and water depletion induced by the administration of furosemide, the natriorexigenic and dipsogenic responses were more intense in rats treated with PCPA than in control animals. The natriorexigenic and dipsogenic responses obtained with the administration of isoproterenol also provide evidence agreeing with this hypothesis, since expression of this behavior during $\beta$-adrenergic stimulation occurs later and at a 


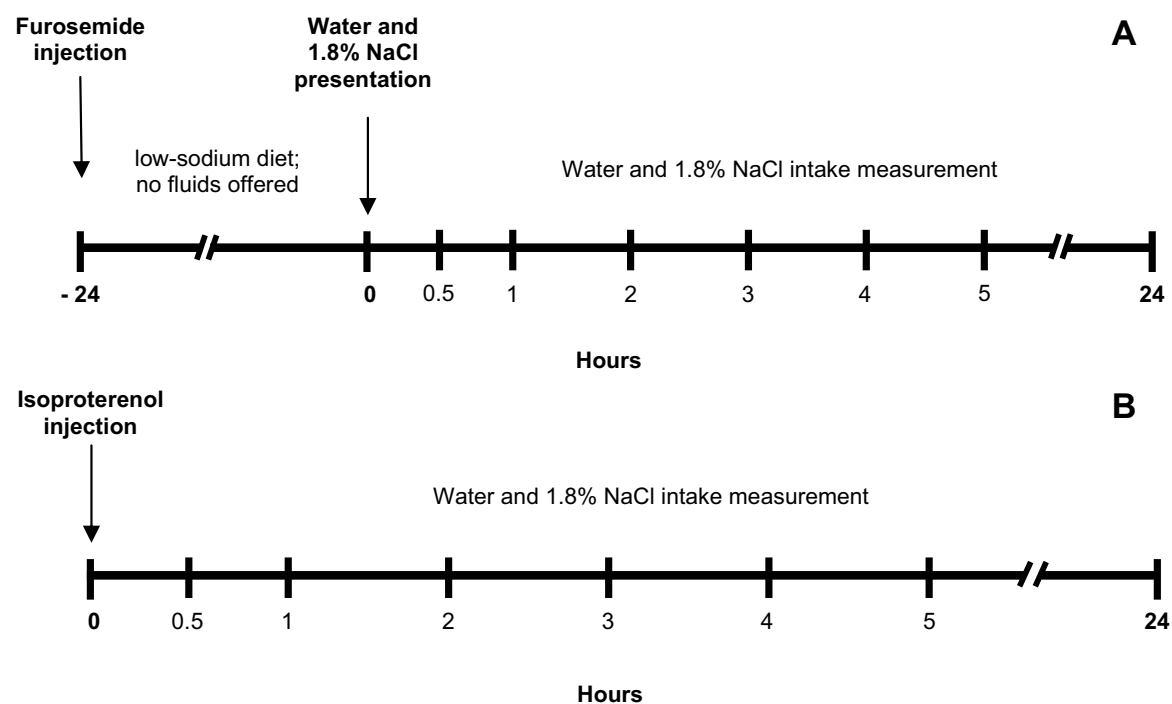

Fig. 1 - Schematic representation of the experimental protocols used in the evaluation of $1.8 \%$ $\mathrm{NaCl}$ and water intake in rats treated with p-chlorophenylalanine (PCPA) and depleted of sodium by furosemide (A) or injected with isoproterenol (B).

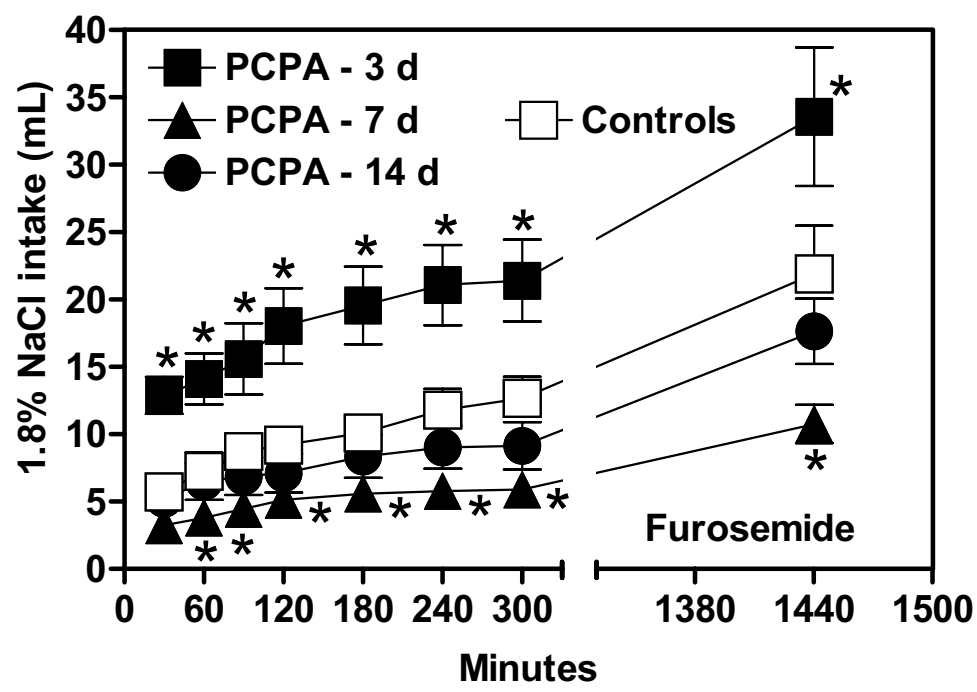

Fig. 2 - Chronic effect of treatment with p-chlorophenylalanine (PCPA, 300 $\mathrm{mg} / \mathrm{kg}$, ip , for 2 days), 3, 7 and 14 days after the first injection, on the natriorexigenic response induced by sodium depletion mediated by furosemide $(20 \mathrm{mg} / \mathrm{kg}$, $s c, 24 \mathrm{~h}$ before beginning of experiment). Mean values represent cumulative $1.8 \% \mathrm{NaCl}$ intake from $30 \mathrm{~min}$ up to $24 \mathrm{~h}$. Data are reported as means $\pm \mathrm{SE}$. ${ }^{*} P<0.05$ compared to controls. 


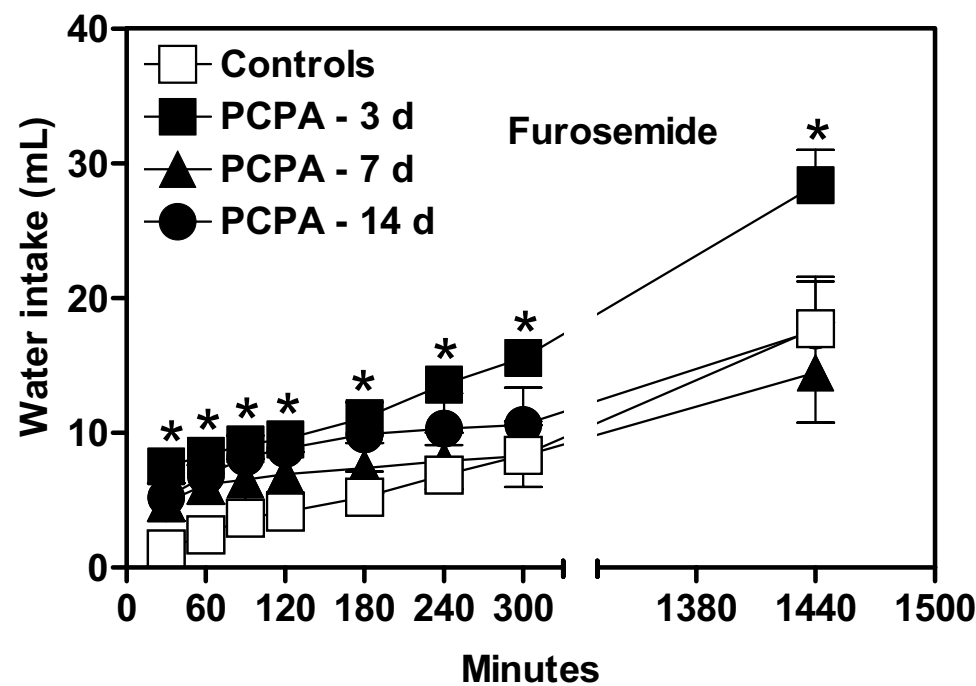

Fig. 3 - Chronic effect of treatment with p-chlorophenylalanine (PCPA, 300 $\mathrm{mg} / \mathrm{kg}$, ip, for 2 days), 3, 7 and 14 days after the first injection, on the dipsogenic response induced by sodium depletion mediated by furosemide $(20 \mathrm{mg} / \mathrm{kg}, s c$, $24 \mathrm{~h}$ before beginning of experiment). Mean values represent cumulative water intake from $30 \mathrm{~min}$ up to $24 \mathrm{~h}$. Data are reported as means $\pm \mathrm{SE}$. ${ }^{*} P<0.05$ compared to controls.

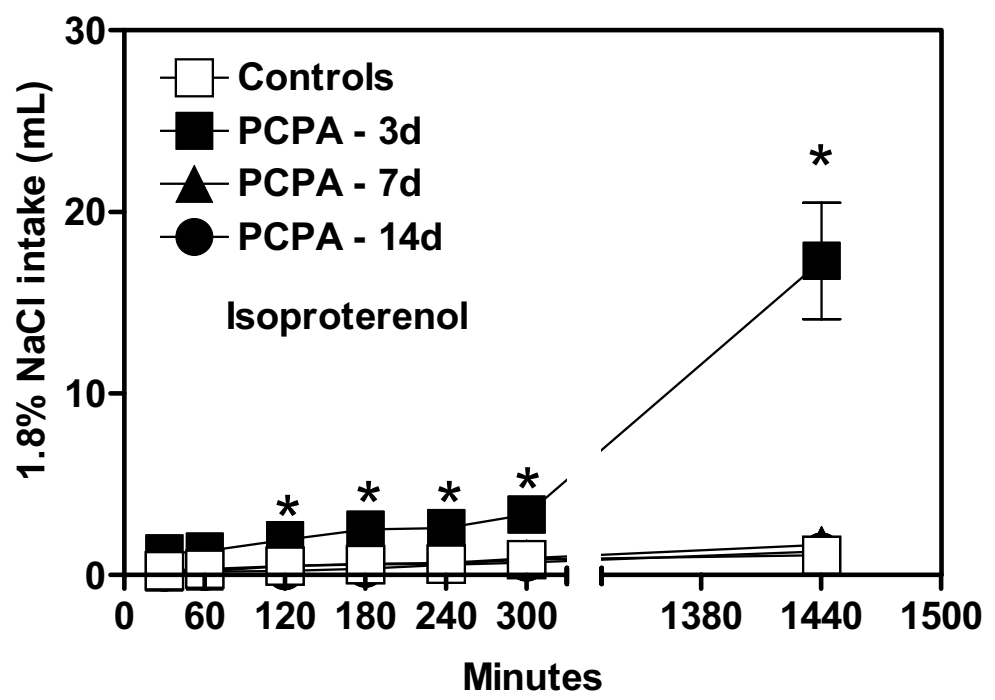

Fig. 4 - Chronic effect of treatment with p-chlorophenylalanine (PCPA, 300 $\mathrm{mg} / \mathrm{kg}$, ip, for 2 days), 3, 7 and 14 days after the first injection, on the natriorexigenic response developed after treatment with isoproterenol $(300 \mu \mathrm{g} / \mathrm{kg}, s c)$. Mean values represent cumulative $1.8 \% \mathrm{NaCl}$ intake from $30 \mathrm{~min}$ up to $24 \mathrm{~h}$. Data are reported as means $\pm \mathrm{SE}$. ${ }^{*} P<0.05$ compared to controls. 


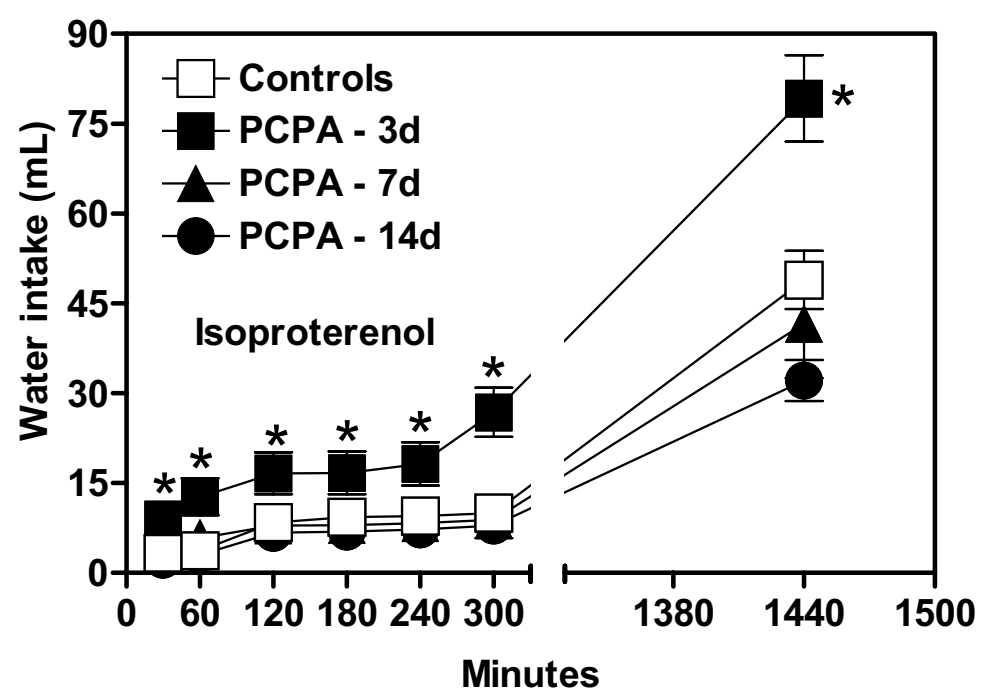

Fig. 5 - Chronic effect of treatment with p-chlorophenylalanine (PCPA, 300 $\mathrm{mg} / \mathrm{kg}$, ip, for 2 days), 3, 7 and 14 days after the first injection, on the dipsogenic response induced after treatment with isoproterenol $(300 \mu \mathrm{g} / \mathrm{kg}, s c)$. Mean values represent cumulative water intake from $30 \mathrm{~min}$ up to $24 \mathrm{~h}$. Data are reported as means \pm SE. ${ }^{*} P<0.05$ compared to controls.

lower magnitude in normal rats (Fitzsimons 1998). In both conditions, the systemic generation of ANG II is augmented and, at least in the case of sodium and water depletion, the angiotensinergic activity of prosencephalic loci involved in sodium appetite expression also shows a concomitant increase (De Luca et al. 1992, Fitzsimons 1998). These observations support evidence recently obtained in our laboratory (submitted for publication) demonstrating that the deficit in brain serotonergic transmission after electrolytic or ibotenic lesion of the DRN exacerbates brain angiotensinergic activity, with a consequent increase of the natriorexigenic response. A single injection of PCPA induces a decrease in brain serotonin content to levels below 20\% two days after administration (Cooper et al. 1996). In the present model, the reduction in brain serotonin content possibly compromised ascending serotonergic transmission mediated by homeostatic mechanisms of water-electrolyte and cardiovascular regulation originating from viscerosensory information and from prosencephalic integrative processes.
One finding that called our attention was the decrease in the natriorexigenic response in rats treated with PCPA to levels below those observed for control animals 7 days after the first injection. We believe that this is due to a rebound effect resulting from the adaptive plasticity of serotonergic neurons stimulated by serotonin depletion. Probably, this response involves overexpression of the TPO gene and de novo synthesis of the enzyme (Richard et al. 1990). In addition, serotonergic plasticity involves a concomitant increase in postsynaptic activity. Brain serotonin depletion promotes the upregulation of 5HT2C receptors and a subsequent increase in postsynaptic activation, factors that further explain our results (Fiorella et al. 1995). Recent data from our laboratory have demonstrated that stimulation of 5-HT2C receptors modulates sodium appetite induced by paradigms of sodium and water depletion in rats with serotonergic hypofunction during hypothyroidism (Badauê-Passos et al. 2003).

Present results show that treatment with the brain serotonin depletor, PCPA, exaggerates sodium 
appetite in paradigms of sodium and water depletion or after $\beta$-adrenergic stimulation, with an increase in brain angiotensinergic sensitivity/excitability being observed in both situations (Fitzsimons 1998). Deficient brain serotonergic function has been related to the development of anxiety and depression (Meltzer and Lowy 1987, Curzon 1988, Charney et al. 1990). It remains to be investigated whether maintenance of the serotonergic hypofunction status for prolonged periods of time is accompanied by increased sodium appetite and by the development of cardiovascular alterations. An increase in $\mathrm{NaCl}$ intake is known to contribute to the induction of water-electrolyte and cardiovascular alterations followed by hypertension (Denton et al. 1984, 1995, Fitzsimons 1998). Thus, an increased risk of developing hypertension is present during the course of anxiety and depression (Jonas and Lando 2002, Zamorski and Ward 2000, Ostroumova et al. 2002, Rutledge and Hogan 2002).

Future studies should focus on other paradigms of serotonin depletion in order to elucidate the mechanisms responsible for the alterations in waterelectrolyte homeostasis and sodium appetite, and to establish straighter correlations with the cardiovascular hypertensive disturbances that develop in affective disorders originating during serotonergic hypofunction.

\section{ACKNOWLEDGMENTS}

This research was supported by PRONEX (CNPq/ MCT). Hawlinston R. Cavalcante Lima, and Haerishton R. Cavalcante-Lima and Pedro L. Cedraz-Mercez were recipients of Scientific Initiation Fellowships from CNPq and FAPERJ, respectively.

\section{RESUMO}

Objetivamos avaliar a influência da depleção cerebral de serotonina no apetite por sódio. Ratos depletados de serotonina através da administração sistêmica de paraclorofenilalanina $(300 \mathrm{mg} / \mathrm{kg}$, ip, por 2 dias) exibiram intensa resposta natriorexigênica induzida pela depleção de só- dio (furosemida, $20 \mathrm{mg} / \mathrm{kg}, s c, 24 \mathrm{~h}$ antes da oferta de água e $\mathrm{NaCl} 1.8 \%$ ). A ingestão de $\mathrm{NaCl} 1,8 \%$ atingiu valores sempre acima do grupo controle $(12,9 \pm 1,4$ e 21, 4 $\pm 3,0$ $\mathrm{mL}$ vs $5,7 \pm 1,2$ e $12,7 \pm 1,6 \mathrm{~mL}, 30$ e $300 \mathrm{~min}$ após apresentação de água e salina hipertônica, $P<0$, 05). Ao final de $24 \mathrm{~h}$ a resposta natriorexigênica ainda mantinha-se significativamente mais elevada em relação aos controles $(33,6 \pm 5,1$ vs $21,9 \pm 3,6 \mathrm{~mL}, P<0,05) \mathrm{e}$ comparável aos controles no $14^{\circ}$ dia. Ratos depletados de serotonina exibiram uma precoce resposta natriorexigênica após administração de isoproterenol, no terceiro dia após a primeira injeção de paraclorofenilalanina. $\mathrm{O}$ aumento da ingestão de $\mathrm{NaCl}$ 1,8\% iniciou-se aos $120 \mathrm{~min}$ $(1,9 \pm 0,3$ vs $0,45 \pm 0,3 \mathrm{~mL}, P<0,05)$ e manteve-se elevada ao final de $24 \mathrm{~h}(17,3 \pm 3,2$ vs $1,1 \pm 0,5 \mathrm{~mL}$, $P<0,05)$ após a oferta de fluidos. Decorridos sete e 14 dias a resposta natriorexigênica tornou-se comparável à dos controles. Os dados apresentados demonstram que a depleção de serotonina cerebral com paraclorofenilalanina, exagera o apetite por sódio em paradigma de depleção de sódio ou após estimulação $\beta$-adrenérgica.

Palavras-chave: apetite por sódio, depleção cerebral de serotonina, depleção de sódio e água, isoproterenol, sistema serotonérgico.

\section{REFERENCES}

Badauê-Passos D Jr, Ventura RR, Silva LFS, OliVARES EL AND REIS LC. 2003. Effect of brain serotoninergic stimulation on sodium appetite in euthyroid and hypothyroid rats. Exp Physiol 88: 251-260.

Charney DS, Woods SW, Krystal JH and Heninger GR. 1990. Serotonin function and human anxiety disorders. In: Whitaker-Azmitia PM AND PerOUTKA SJ. (Eds.), The neuropharmacology of serotonin, Ann NY Acad Sci, New York, p. 558-573.

Cooper JR, Bloom FE and Roth RH. 1996. Serotonin (5-Hydroxytryptamine) and Histamine. In: BLOOM FE. et al. (Eds.), The Biochemical basis of neuropharmacology, 7th ed., New York: Oxford University Press, p. 352-409.

Curzon G. 1988. Serotonergic mechanisms of depression. Clin Neuropharmacol 11 (Suppl 2): S11-S20.

De luca la Jr, Galaverna O, Schulkin J, Yao SZ AND EPSTEIN AN. 1992. The anteroventral wall of the 
third ventricle and the angiotensinergic component of need-induced sodium intake in the rat. Brain Res Bull 28: 73-87.

De Luca LA Jr, Xu Z, Schoorlemmer GH, Thunhorst RL, Beltz TG, Menani JV and Johnson AK. 2002. Water deprivation-induced sodium appetite: humoral and cardiovascular mediators and immediate early genes. Am J Physiol 282: R552-R559.

Denton DA, Coghlan JP, Fei DT, McKinley M, Nelson J, Scoggins B, Tarjan E, Tregear GW, Tresham JJ and Weisinger R. 1984. Stress, ACTH, salt intake and high blood pressure. Clin Exp Hypertens A 6: 403-415.

Denton DA, Weinsiger R, Mundy NI, Wickings EJ, Dixson A, Moisson P, Pingard AM, Shade R, Carey D, Ardaillou R, Paillard F, Chapman J, Thillet J AND Michel JB. 1995. The effect of increased salt intake on blood pressure of chimpanzees. Nat Med 1: 1009-1016.

Fiorella D, Helsley S, LorRain DS, RABIN RA AND WINTER JC. 1995. The role of the 5-HT2A and 5HT2C receptors in the stimulus effects of hallucinogenic drugs. III: The mechanistic basis for supersensitivity to the LSD stimulus following serotonin depletion. Psychopharmacology 121: 364-372.

Fitzsimons JT. 1998. Angiotensin, thirst, and sodium appetite. Physiol Rev 78: 583-686.

Franchini LF, Johnson AK AND Vivas L. 2002. Sodium appetite and Fos activation in serotonergic neurons. Am J Physiol 282: R235-R243.

Houpt KA And Epstein AN. 1971. The complete dependence of $\beta$-adrenergic drinking on the renal dipsogen. Physiol Behav 7: 897-902.

JoNAS BS AND LANDo JF. 2002. Negative affect as a prospective risk factor for hypertension. Psychosom Med 62: 188-196.

Koe KB AND Weissman A. 1966. p-Chlorophenylalanine: a specific depletory of brain serotonin. J Pharmacol Exp Ther 154: 499-516.
McCann SM, Gutkowska J AND Antunes-RodRIGUES J. 2003. Neuroendocrine control of body fluid homeostasis. Braz J Med Biol Res 36: 165-181.

Meltzer HY And Lowy MT. 1987. The Serotonin hypothesis of depression. In: Meltzer HY. (Ed.), Psychopharmacology: The third generation of progress, New York: Raven Press, p. 513-526.

Menani JV, Thunhorst RL and Johnson AK. 1996. Lateral parabrachial nucleus and serotonergic mechanisms in the control of salt appetite in rats. Am J Physiol 270: R162-R168.

Ostroumova OD, Mamaev VI, Pervichko EI and Baranovskaia VV. 2002. Hypertension and anxiety states. Kardiologiia 42: 95-98.

Reis LC, Ramalho MJ and Antunes-Rodrigues J. 1991. Effect of central administration of serotoninergic agonists on electrolyte excretion control. Braz J Med Biol Res 24: 633-641.

Reis LC, Ramalho MJ And Antunes-Rodrigues J. 1992. Brain serotoninergic stimulation reduces the water intake induced by systemic and central betaadrenergic administration. Braz J Med Biol Res 25: 529-536.

Reis LC, Ramalho MJ, Favaretto AL, Gutkowska J, McCann SM and Antunes-Rodrigues J. 1994. Participation of the ascending serotonergic system in the stimulation of atrial natriuretic peptide release. Proc Natl Acad Sci USA 91: 12022-12026.

Richard F, Sanne JL, Bourde O, Weissman D, Ehret M, Casch C, Maitre M and Pujol JF. 1990. Variation of tryptophan-5-hydroxylase concentration in the rat raphe dorsalis nucleus after p-chlorophenylalanine administration. I. A model to study the turnover of the enzymatic protein. Brain Res 536: 41-45.

Rutledge T And Hogan BE. 2002. A quantitative review of prospective evidence linking psychological factors with hypertension development. Psychosom Med 64: 758-766.

ZAMORSKI MA AND WARD RK. 2000. Social anxiety disorder: common, disabling, and treatable. J Am Board Fam Pract 13: 251-260. 